\title{
Constraints and Challenges Facing the Small Scale Farmers in Limpopo Province, South Africa
}

\author{
Sylvester Mpandeli ${ }^{1,2} \&$ Phokele Maponya ${ }^{3}$ \\ ${ }^{1}$ University of Venda, School of Environmental Sciences, Department of Geography and Geo - Information \\ Sciences, Thohoyandou, South Africa \\ ${ }^{2}$ Water Research Commission of South Africa, Gezina, South Africa \\ ${ }^{3}$ Agricultural Research Council-Vegetable and Ornamental Plant Institute, Pretoria, South Africa \\ Correspondence: Sylvester Mpandeli, Water Research Commission of South Africa, Gezina, South Africa. E-mail: \\ sylvesterm@wrc.org.za
}

Received: November 7, 2013

Accepted: January 13, 2014 Online Published: March 15, 2014

doi:10.5539/jas.v6n4p135

URL: http://dx.doi.org/10.5539/jas.v6n4p135

\begin{abstract}
Macro- and micro-structural constraints, including those linked to and exacerbated by historical, natural and financial factors are some of the many stressors facing small-scale farmers in Limpopo Province. The challenge is to co-design ways to effectively manage these constraints with development actions. Small scale farmers in South Africa are still facing major challenges in the agricultural sector. In this paper some of the challenges faced by small-scale farmers in the Limpopo Province have been identified. Some of the challenges found during the formal surveys and focus group meetings in the Tshakhuma, Rabali and Tshiombo areas were those linked to financial, assets, land ownership and biophysical factors. Specific constraints included: (a) Market information and market access; (b) Price of inputs, for example fertilizer and herbicides; (c) Availability of inputs; (d) Irrigation; (e) Cost of transport, and Natural constraint.
\end{abstract}

Keywords: agricultural production and productivity, small scale farmers, Limpopo Province, South Africa

\section{Introduction}

In this paper, challenges faced by small scale farmers in the Tshakhuma, Rabali and Tshiombo areas in Limpopo Province, South Africa over the past five years were examined. Some of the wider structural constraints are discussed with detailed reference to the study sites. Small-scale farmers in South Africa have continued to maintain a livelihood in the face of unfavorable conditions. Different challenges facing poor-resource farmers in the Limpopo Province for the past the past two decades were identified or highlighted by several authors including (Azan \& Besley, 1991; Makhura, 2001), these include inadequate access to productive resources, price of inputs such as herbicides and fertilisers, market access and cost of transport. However, it is important to note that these challenges facing poor resource farmers in Limpopo Province hinders agricultural development not only in Limpopo but also in other provinces in country, e.g. Eastern Cape, Mpumalanga, Free State (Mpandeli, 2006). In order to maintain high levels of production and quality it is necessary for farmers to access all the required inputs. As shown in other papers published by, Makhura, 2001, Mpandeli and Maponya (2012) the majority of people residing in Limpopo Province are poor. According to a discussion on food security by the Department of Agriculture and Land Affairs (DALA, 1997) and the Ministry of Agriculture and Land Affairs (MALA, 1998), many households are vulnerable to food insecurity including those in Limpopo Province (e.g. FIVIMS, 2003).

In order to generate enough income these farmers tend to engage in off-farm or non-farm income - generating activities Makhura (2001); Maponya and Mpandeli (2012). To a large extent the process of agricultural transformation in South Africa involves moving households from subsistence production to producing for the market (Makhura, 2001). Producing for the market provides a number of benefits and advantages. In particular, rural employment is promoted and income is generated Christodoulou and Vink (1990); Ngqangweni (2000). Furthermore, several studies Elwert and Fett, 1982, Delgado et al. (1998); Ngqangweni (2000) have shown positive and strong multiplier effects of investing in agriculture. In other words, agriculture has an important role to play in fostering rural development and poverty alleviation. 
Vhembe district in Limpopo Province has been affected by drought and flooding throughout history. These events have usually resulted in low production. One constrain to drought coping is management and decision making, at various levels. Factors exacerbating weak drought management at various levels (e.g. local and national) include the lack of a detailed understanding of the role and value of various interventions, including early-warning information. The aims of this paper are: (a) To assess past and current constraints that farmers are facing in the Tshiombo, Tshakhuma and Rabali areas in Vhembe district in Limpopo Province; (b) To highlight agricultural constraints threatening their livelihoods of farmers in the Tshiombo, Rabali and Tshakhuma areas in Vhembe district and to identify current adaptation strategies used by farmers that promotes and builds resilience and adaptive capacity in the Vhembe district.

\section{Methodology}

Three study areas were selected for this research. The study areas are situated in the Vhembe district, which is situated approximately $184 \mathrm{~km}$ north of Polokwane. The research sites are located in rural areas with proximity to larger areas of commercial activity: for example, Tshiombo village is $35 \mathrm{~km}$ from Thohoyandou Central Business District (CBD), Tshakhuma village is $37 \mathrm{~km}$ away from Thohoyandou CBD and $40 \mathrm{~km}$ away from Makhado (Figure 1).

(a) Tshakhuma area is situated $28^{\circ} 30^{\prime}$, East longitude and $24^{\circ} 25^{\prime}$ South latitude $35 \mathrm{~km}$ West of Thohoyandou Central Business District. The following villages share boundaries with Tshakhuma village: Levubu, Elim and Lwamondo. These villages are situated at an altitude of $600 \mathrm{~m}$ above sea level.

(b) Rabali area is situated $30^{\circ} 30^{\prime}$ East longitude and $24^{\circ} 58^{\prime}$ South latitude, $25 \mathrm{~km}$ from Thohoyandou Central Business District and $15 \mathrm{~km}$ from Makhado (formerly known as Louis Trichardt). The following villages share boundaries with Rabali village: Raliphaswa, Dzanani, Mauluma and Ha-Matidza. These villages are situated at an altitude of between $600-700 \mathrm{~m}$ above sea level.

(c) The Tshiombo area is situated $30^{\circ} 50^{\prime}$ East Longitude and $22^{\circ} 79^{\prime}$ South Latitude, $35 \mathrm{~km}$ North of Thohoyandou Central Business District. The following villages share boundaries with Tshiombo: Tshandama, Makonde, Pile and Thengwe. These villages are situated at an altitude of $650 \mathrm{~m}$ above sea level.

Map of study area
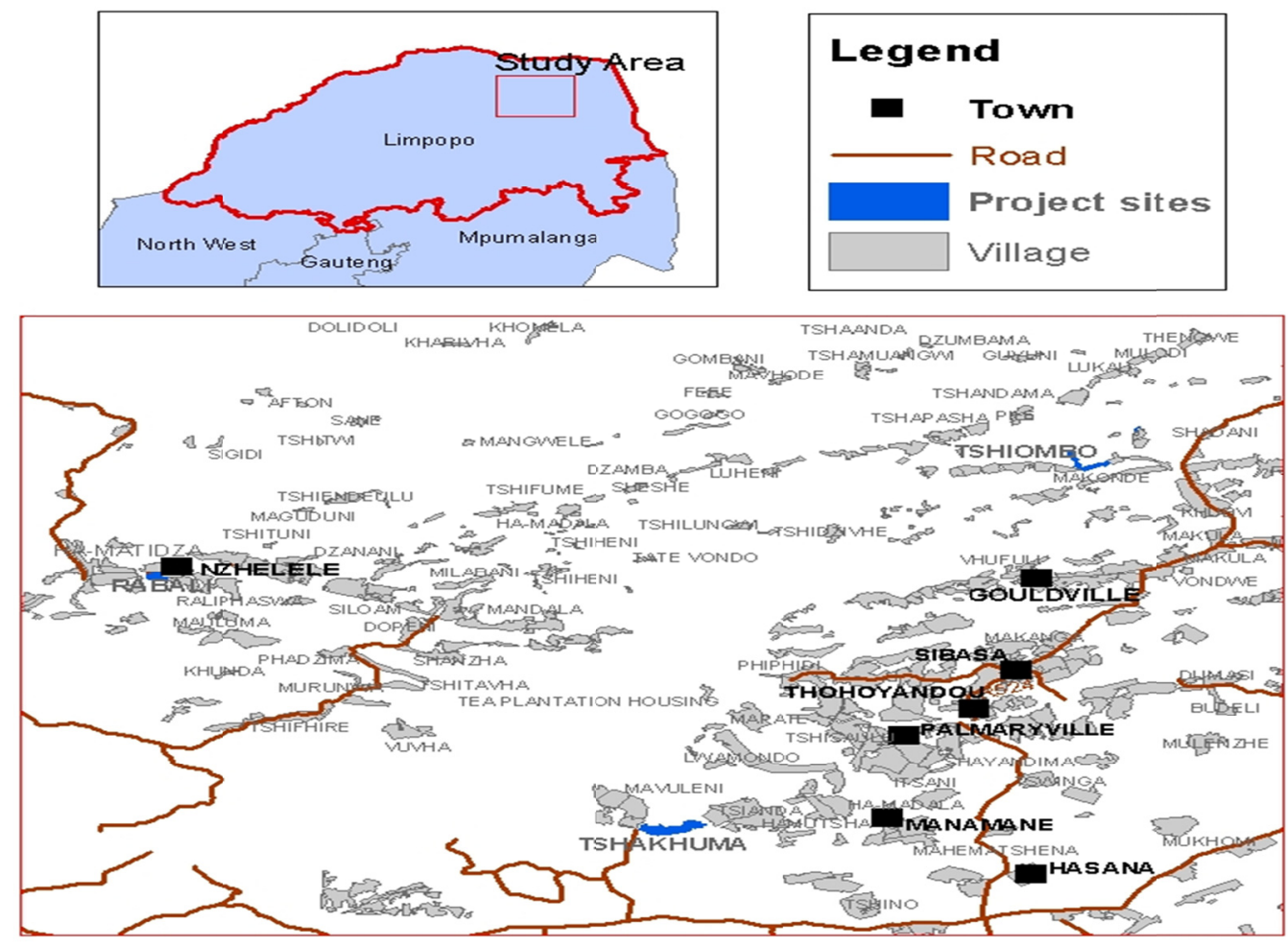

Figure 1. Map of Limpopo Province showing different villages in the Vhembe district (former Venda homeland)

(ARC-ISCW, 2003) 
Pre-survey visit: A pre-survey visit was arranged within the selected areas with the tribal authorities of each area. The objectives of the pre-survey visit were: to meet the tribal authorities such as headman, chief and civil organisations of the selected area; to demonstrate the objective of the survey and the content of the intended questionnaires; to introduce the survey team to the tribal authorities and to seek permission to be able to work in each of the communities; to meet agricultural officials including district officials in Limpopo Provincial Department of Agriculture (LPDA) and officials involved in the community (for example, extension officers).

Data for this study was collected over a one-year period from the communities of Tshakhuma, Rabali and Tshiombo within the Vhembe district. The data were obtained in two different but consecutive phases. Two methods were employed: Formal survey and non-structured surveys. Household surveys were conducted during 2003/2004 seasons in three different villages in the Vhembe district (Tshakhuma, Rabali and Tshiombo). A total of 90 farmers were interviewed during the formal survey; they were chosen using random sampling techniques. It is important to note that 30 farmers were interviewed in each village (Tshakhuma, Rabali and Tshiombo). Methods used to achieve the aim included literature reviews, survey instruments, participatory rural appraisal and focus group with several farmers in the area, as well as stakeholder and key informant interviews.

\section{Results and Discussion}

Different challenges facing poor-resource farmers in the study sites for the past five years were identified; these include inadequate access to productive resources, price of inputs such as herbicides and fertilisers, market access and cost of transport. All the above-mentioned challenges facing poor resource farmers in the study sites hinders agricultural development in the Vhembe district. In order to maintain high levels of production and quality it is necessary for farmers to access all the required inputs. Some farmers indicated that, with the launch of the Comprehensive Agricultural Support Programme (CASP) by the Department of Agriculture, they can overcome some of the challenges mentioned. CASP offers a wide range of support services including financial support, purchase of inputs, infrastructure development, training and capacity building.
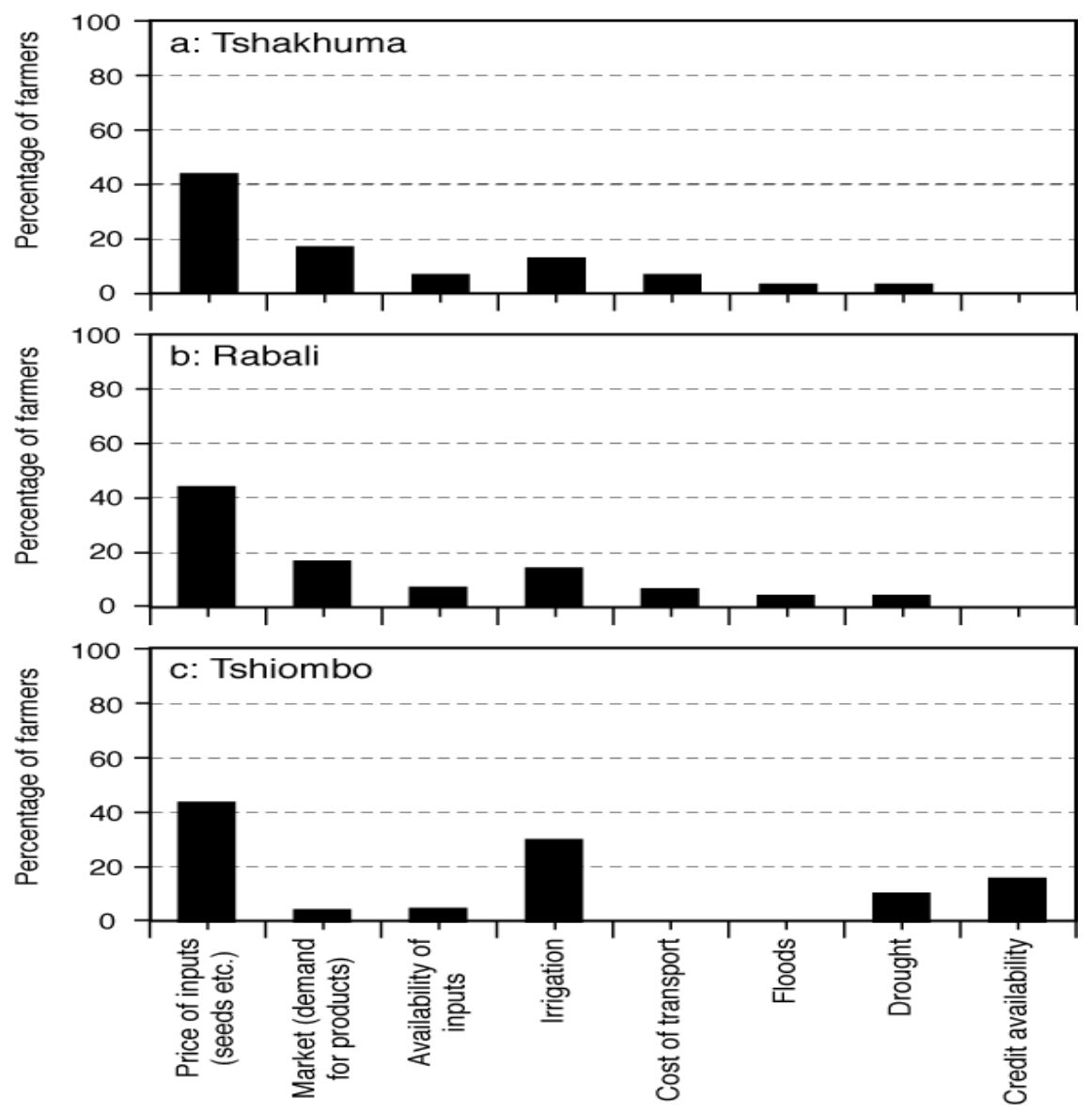

Figure 2. Challenges faced by farmers in the Vhembe district. (a) Tshakhuma, (b) Rabali and (c) Tshiombo areas during the past five years 
Results from the farmer focus group and surveys indicated that at least half of the farmers in the Tshakhuma, Rabali and Tshiombo areas identified the high price of inputs as the first major challenge including, for example, high price of fertilisers, seeds and herbicides (Figure 2a, 2b, 2c). During the focus group farmers mentioned price of inputs, market, cost of transport and irrigation as the major challenges in the Tshakhuma, Rabali and Tshiombo areas. The results from the focus group and surveys are also remarkably similar in all the three study areas. Focus group discussions were held twice in the Tshakhuma, Rabali and Tshiombo areas.

Effective market interaction was the second most important challenge viewed by respondents in the Tshakhuma and Rabali areas. At least $17 \%$ of the respondents in the Tshakhuma and Rabali areas viewed market problems as an obstacle to market their products in a formal market (Figure 2a, 2b). Some farmers indicated that they were willing to supply the market but there was limited market access and those who did have market access made it difficult for other farmers to send their products to the market by purposely increasing the transport cost (McIntiure \& Delgado, 1985; Ngqangweni, 2000; Makhura, 2001) and Mpandeli (2006).

Another $13 \%$ of the respondents in the Tshakhuma and Rabali areas viewed irrigation as the third major challenge in their farming business. At least seven percent of the respondents in the Tshakhuma and Rabali areas indicated that the cost of transport was the fourth major challenge in the Tshakhuma and Rabali areas. The occurrence of droughts and floods did not emerge as key constraints; rather the structural issues of access to markets and service appeared to be key. The results indicated that the majority of farmers consider price of inputs, irrigation and market issues as major challenges across all sites, particularly Tshakhuma and Rabali. In the Tshiombo area at least more than $30 \%$ of the farmers viewed irrigation as the fourth major challenges compared to the other two sites.

Farmers in the Tshiombo area faced a number of different challenges to farmers in the other study sites that deserve particular mention. Here at least $30 \%$ had access to irrigation water, even though some farmers were misusing and mismanaging water resulting in a shortage of water, especially during drought periods. Tshiombo farmers are still using cemented furrow irrigation system and this resulted in some water being lost through seepage, drainage and evaporation. Some farmers indicated that periods of water shortage are also caused by the low water pressure system installed by the Department of Water Affairs. Other farmers stated that the problem was with the farmers themselves because some farmers who had plots closer to the dam were unreliable and trustworthy. They took hours to give other farmers access to irrigation water with some only receiving water after long periods of time. These were usually farmers who had plots several kilometers away from the dam and who were often the victims of the irrigation politics in the area.

At least $17 \%$ of the respondents in the Tshiombo area viewed credit availability as the third major challenge (Figure 2c). Previously these farmers used to obtain credit from the Venda Development Corporation before it was disbanded. During that period Tshiombo farmers managed to produce good - quality products that met market standards because they had enough capital. Currently the institutional set up has changed; the majority of farmers are finding it difficult to access enough capital even though the provincial Department of Agriculture has got several financial support programmes.

Less than five percent of the respondents in the Tshiombo area viewed availability of inputs, especially seeds, as a major challenge over the past five years, compared to farmers in the Tshakhuma and Rabali areas. This may be due to the fact that the majority of farmers in the area have been trained to produce hybrid seeds by experts from Agricultural Research Council-Summer Grain Institute and Madzivhandila College of Agriculture. Some of these farmers have indicated that they are using hybrid seeds as part of the adaptation strategies, these hybrid seeds produce good yields. As in the previous case, floods, extreme temperatures and droughts were not regarded as challenges by Tshiombo farmers, even though in the year 2000 the majority of farmers had lost large production volumes due to floods. More detailed information obtained from farmers is provided below to expand on some of the inputs illustrated in previous sections (e.g. credit and finance and market interaction).

In all the three study sites crops were not only grown for consumption, but also for commercial purposes. The majority of the farmers in the Tshakhuma area sold their products to the local market and to "others" for example, to friends and neighbours (Figure 3a, 3b, 3c). Only small numbers of farmers had access to mechanisms to distribute their products to different markets such as local, provincial and national markets. These factors were also highlighted by Makhura (2001) it looks like the situation has not changed since early year 2000. Farmers in the Tshakhuma area were not marketing their products to provincial and national markets as they have indicated that lack of market information and transport and also limited access due to the distance to the market. At least $82 \%$ of the farmers distributed their products to local markets in the Tshakhuma area.

Another two percent of the respondents indicated that they were distributing their products to relatives, friends and neighbours for non-profit purposes, especially when there was good production, in order to avoid unnecessary 
losses. The majority of these farmers in the Tshakhuma area were heavily dependent on their crops to generate a source of income. Some of the farmers in the Tshakhuma area indicated that today their biggest clients or customers are informal traders and street vendors in villages around Tshakhuma, Tshalovha, and Lwamondo.
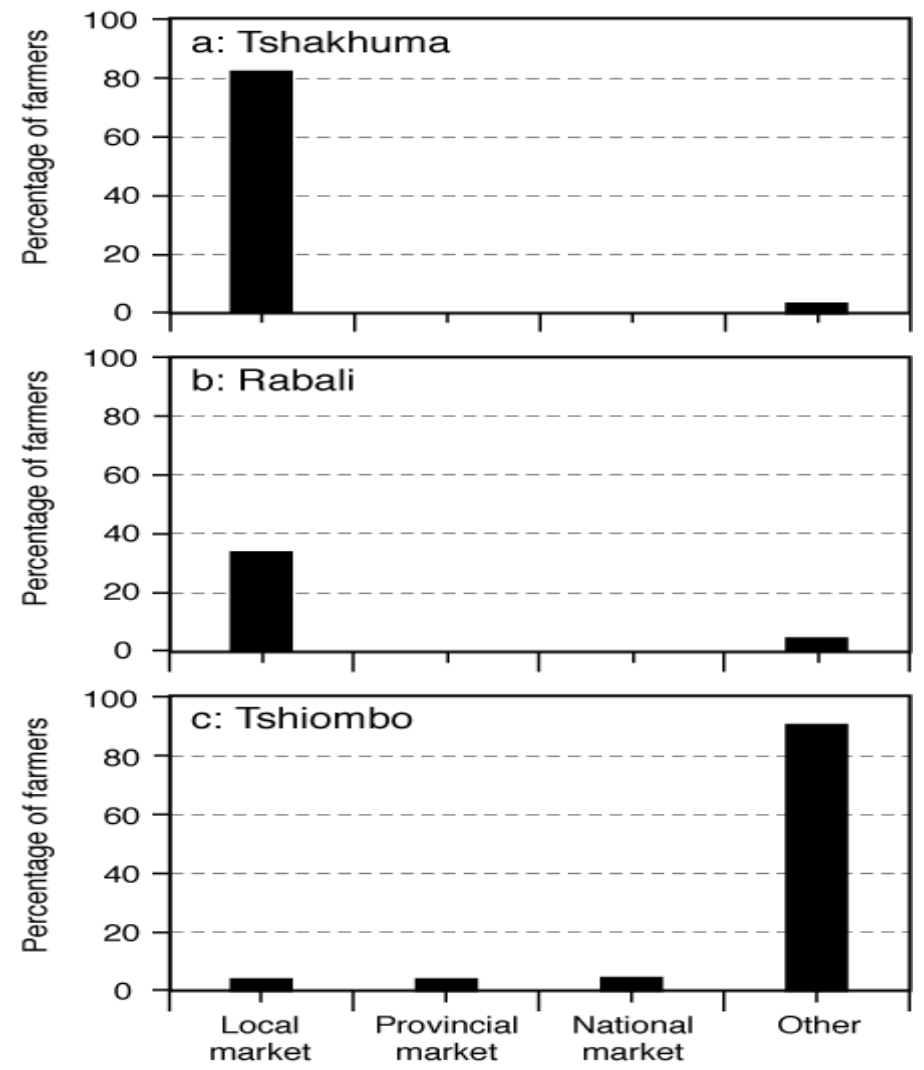

Figure 3. Markets utilised by farmers in the Vhembe district. (a) Tshakhuma,(b) Rabali and (c) Tshiombo areas

The results indicated that the majority of the farmers (33\%) in the Rabali area are distributing their products to the local market; they stated that they were producing products that meet local market standards and other products are produced for household consumption (Figure 3b). Of all the farmers interviewed, none of them supplied the provincial market or the national market. The fact that these farmers did not have access to the competitive market denied them opportunities to compete with other commercial farmers. Three percent of the farmers interviewed indicated that instead of distributing their products to the local market, they shared with relatives and neighbours who were not farming and the remaining products were to ensure household security. During the formal surveys in the Tshiombo area, it was found that $90 \%$ of the respondents produce products for households only, although some of these farmers shared their products with friends, relatives and neighbours. This resulted in them having a high loss of production if they produced high volumes of products (Figure 3c).

The majority of these farmers in all the study sites indicated that they were willing to distribute their products to the market but had difficulties because of the strict requirement in the formal market - e.g. demand for high-quality products and this it was also highlighted in other studies (Coase, 1960; Bembridge, 1994; Delgado, 1999; Holloway et al., 2000; Makhura, 2001). Only two percent of the respondents indicated that they were supplying provincial and national markets. It is important for Tshiombo farmers to be encouraged to start producing high-quality products that meet the market standards because they have access to irrigation and they can also produce their own hybrid seeds.

Some of the macro structural constraints facing farmers in these areas have been explained by several researchers. One key constraint that is closely linked to the past is access to land and land ownership. In South Africa, the historical and political complexity of the land issue, rights and entitlement makes the question of land tenure very relevant. Most landholders, including farmers, maintain that without secure tenure, through title or certificate of occupancy, evidence of ownership or rights over property on that land is not guaranteed (FOA/ ARDRI 1996 and 
Makhura, 2001). No particular member of the community has individual rights or access to land, especially as no registered title deeds have been given at any point in time (Van Averbeke et al., 1998). Secure land tenure is a necessary pre-condition for the adoption of long-term sustainability of farming practices (Van Averbeke et al., 1998; Makhura, 2001).

Different forms of tenure systems and land ownership - tribal, state ownership, trust land, quitrent and freehold are present in all three study areas. The land tenure system in the former Venda homeland is primarily dominated by communal land. Community members, in accordance with the recognised traditional communal system of land tenure, use most of the lands in the tribal communities (Romuld \& Sandham, 1995; Mudau, 1997; Sweet, 1998; Makhura, 2001; Mpandeli, 2006). In the interest of intensive use of irrigated land, it is important that landholding households that are no longer interested in or no longer capable of producing on their allocated land make their land available to other households seeking access to more land (Van Averbeke et al., 1998; Stevens, 2012).

As mentioned previously, farmers who are farming in a communal area have a shortage of equipment, lack of capital and land to grow enough crops. The communal farming sector has limitations in the use of technology and external inputs - e.g. planting maize without using fertiliser.
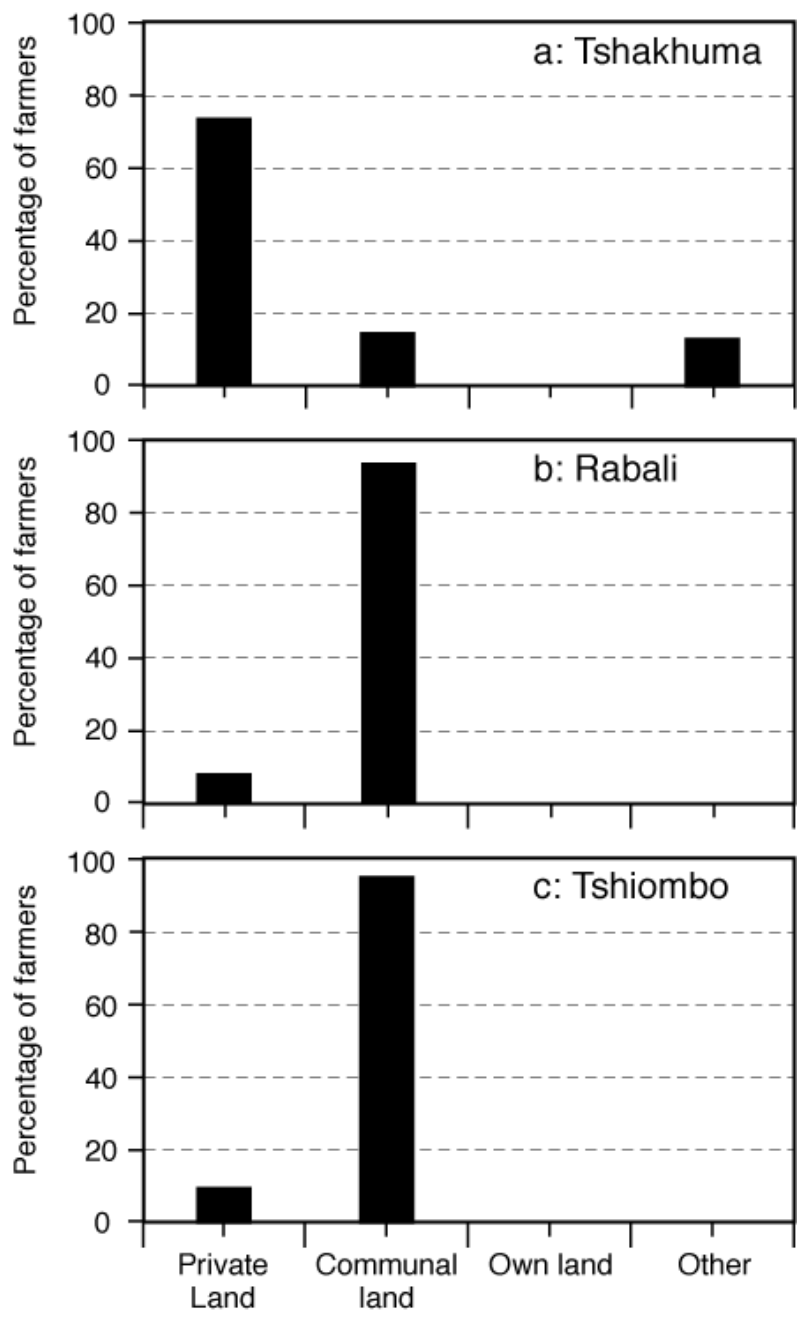

Figure 4. Types of land . (a)Tshakhuma, (b) Rabali and (c) Tshiombo areas

The majority of the farmers (73\%) in the Tshakhuma area farmed on private land, while only $12 \%$ farmed on communal land. Some parts of the Tshakhuma area were given to people through the land redistribution programme. The "other" $12 \%$ occupied mountainous areas, and these farmers planted their crops on steep slopes due to insufficient land availability. These types of farmers obtained land through the local chief (Figure 4a). The local chief is responsible for land allocation and these have caused some discomfort amongst some farmers due to 
nepotism and favouritism. Some of the farmers in the Tshakhuma area claim that even though they are farming in steep slopes, they have the potential to produce good-quality products. Farming in steep slopes is a cause for concern to local agricultural experts, because as time goes on, the area could become unproductive due to soil erosion and the leaching of nutrients which will affect farmers and also enhance land degradation.

Nearly $92 \%$ of the farmers in the Rabali area farmed on communal land, and at least eight percent used private land (Figure 4b). Those on private land were from the chief's family. In the Rabali and Tshiombo areas, for example, there were no farmers farming on the resettlement land because of unavailable of the resettlement programme in both areas. On this communal land, the former Venda homeland administration built a traditional irrigation system in the area to give farmers access to irrigation water.

In the Tshiombo area $98 \%$ of the respondents farmed on communal land, while two percent of the respondents farmed on private land. Both Tshiombo and Rabali farmers farmed on communal and private land. None of the farmers interviewed in the Tshiombo area occupied resettlement land (Figure 4c). Rabali and Tshiombo irrigation schemes were leased to the community through the local chief by the government. In both areas there were no farmers who owned the plots permanently except the local chief. This was a renewable lease agreement between the two parties. Farmers in the Rabali and Tshiombo areas paid R12 every year to the government as lease agreement in order to continue farming.

\section{Conclusions and Recommendations}

Lack of market access was mentioned in all the three study sites as one of the main problems constraining production. Farmers indicated that, even if they were successful producers, if there was no formal market, they would still run at a loss because their products would perish in their storerooms, however, similar observations were noted in the other province such as Eastern Cape. During the focus group meeting at the study sites, more than $70 \%$ of the farmers complained about the lack of market access and the lack of market information. Although more than half of the producers in the study sites produced quality products the problem is that these farmers are resource-poor and struggle to get access to market and market information. If farmers fail to get market access, it is not easy for them to participate in formal market activities. The majority of these farmers are also excluded from participating in the formal market process, due to the following reasons: (a) Lack of transport; (b) Poor access to market information; (c) Lack of formal education by the majority of farmers. However, besides the factors that were highlighted here issues such as extreme climatic events, climate change, climate variability, lack of collateral become an additional burden to the majority of these farmers in order for them to operate effectively and efficiently.

\section{References}

Azan, J. P., \& Besley., T. (1991). Peasant Supply Response under Rationing: The Role of the Food Market. European Journal of Political Economy, 5, 331-343. http://dx.doi.org/10.1016/0176-2680(91)90017-W

Bembridge, T. J. (1994). Protein supplemtary feeding of breeding stock proves profitable under watershed ranching conditions. Rhodes Agricultural Journal, 60, 89-100.

Christodoulou, N. T., \& Vink, N. (1990). The potential for black smallholder farmers' participation in the South African Agricultural economy. Paper presented at the Conference on Land Reform and Agricultural Development, Newick Park Initiative, October 1990, United Kingdom.

Coase, R. H. (1960). The problem of Social Cost, Journal of Law and Economics, 3, 1-44. http://dx.doi.org/10.1086/466560

Crookes, D. (2003). The contribution of livelihood activities in the Limpopo Province: A case study evidence from Makua and Manganeng.

DALA-Department of Agriculture and Land Affairs. (1997). Food Security Policy for South Africa. A Discussion Document. Unpublished report.

Delgado, C. (1999). Sources of Growth in Smallholder Agriculture in Sub-Saharan Africa: The role of Vertical Integration of Smallholders with Processors and Marketers of High Value-Added Items. Agrekon, 38(Special issue), 165-189. http://dx.doi.org/10.1080/03031853.1999.9524913

Delgado, C. L., Hopkins, J., \& Kelly, V. (1998). Agricultural Growth Linkages in Sub-Saharan Africa. IFPRI Research Report No. 107. Washington, D. C.: IFPRI.

Elwert, G., \& Fett, R. (1982). Afrikazwischem Subsistenzkonomie und Imperialis-nus. Frankurt. 
Faculty of Agriculture (FOA) \& Agricultural and Rural Development Research Institute (ARDRI). (1996). Keiskammahoek, Ncora and Qamata irrigation schemes, Summary of report by the Commission of inquiry appointed by the Eastern Cape Province to look for sustainable solutions to problems of large Eastern Cape Irrigation Schemes. Alice, University of Fort Hare.

FIVIMS. (2003). Analysis, Design and Development of a model for a Food Security and Vulnerability Information and Mapping System for South Africa. Report submitted to the Department of Agriculture.

Hobbs, J. E. (1997). Measuring the Importance of Transaction Costs in Cattle Marketing. American Journal of Agriculture Economics, 79, 1083-1095. http://dx.doi.org/10.2307/1244266

Holloway, G., Nicholson, C., Delgado, C., Staal, S., \& Ehuic, S. (2000). Agro-industrialization through Institutional Innovation Transaction Costs, Cooperatives and Milk-Market Development in the East-African Highlands. Agricultural Economics, 23, 279-288. http://dx.doi.org/10.1111/j.1574-0862.2000.tb00279.x

Howel, J. (1985). Recurrent cost and agricultural development. The Russel Press Ltd. Nottingham, UK.

Igodan, C. O. (1996). Survey of rural women in Oyo State Nigeria. Institute of African Studies, Press report, University of Ibadan, Nigeria.

Jaffee, S., \& Morton, J. (1995). Private Sector High -Value Food Processing and Marketing: A synthesis of African Experience. In S. Jaffee, \& J. Morton (Eds.), Marketing Africa's High-Value Foods, Comparative Experience of an Emergent Private Sector. Dubuque: Kendall/Hunt Publishing Company.

Kirsten, J. F. (1994). Agricultural Support Programmes in the Developing Areas of South Africa. Unpublished $\mathrm{PhD}$ thesis, Pretoria: University of Pretoria.

Kirsten, J. F., Sartorius Von Bach, H. J., \& Van Zyl, J. (1993). Evaluation of the Farmer Support Programme: Sub-Assigment (Venda, Lebowa and Kangwane). Final Report on Agricultural Economic Analysis, Unpublished Report.

Kirsten, J. F., Van Zyl, J., \& Vink, N. (1998). The Agricultural Democratization of South Africa. Cape Town, AIPA/Francolin Publishers.

Makhura, T. M. (2001). Overcoming transaction costs barriers to market participation of smallholder farmers in the Northern Province of South Africa. Unpublished PhD thesis, Pretoria, University of Pretoria.

Malambo, L. M. (1988). Rural food security in Zambia. Hamburg, University Press, Michigan State University.

MALA-Ministry of Agriculture and Land Affairs. (1998). Agricultural Policy in South Africa, A Discussion Document. Cape Town: CTP Book Printers.

Maponya, P. I., \& Mpandeli, N. S. (2013. Impact of land ownership on farmers livelihood in Limpopo Province, South Africa. Peak Journal of Agriculture Science.

McIntiure, J., \& Delgado, C. (1985). Statistical Significance of Indicators of Efficiency and Incentives: Example from West African Agriculture. American Journal of Agricultural Economics, 67(4), 733-738. http://dx.doi.org/10.2307/1241812

Mpandeli, N. S. (2006). Coping with climate variability in Limpopo Province. Unpublished PhD thesis, University of Witwatersrand.

Mudau, T. W. (1997). Forage evaluation in the Mopani veld and Lowveld sour bushveld of the Northern Province. Masters submitted to the Department of Plant Production and Soil Science, University of Pretoria, Pretoria, 8.

Ngqangweni, S. S. (2000). Promoting Income and Employment Growth in the Rural Economy of the Eastern Cape through Smallholder Agriculture. Unpublished PhD thesis, Pretoria, University of Pretoria.

Romuld, A., \& Sandham, T. (1995). Present adaptation, social change and communal resource management among rural dwellers in Ciskei, South Africa. Unpublished. MSc. Degree dissertation, Agricultural University of Norway, AS.

Thomas, J. A., \& Stilwell, W. J. (1994). Community participation and sustainable development. Proceedings of the International Workshop in Small holder irrigation, 27-29 April, 1994, Kruger National Park, South Africa, 1-90.

Torkelson, A. B., \& Anandajayasekeram, P. (unknown). Indigenous Knowledge and Sustainable Agriculture. 
Van Averbeke, W. M., Marete, C. K., Igodan, C. O., \& Belete, A. (1998). An investigation into Food Plot Production at Irrigation into Food Plot Production at Irrigation Schemes in Central Eastern Cape. Water Research Commision Report, No. 719/1/98.

Van Rooyen, C. J., Vink, N., \& Christodoulou, N. T. (1987). Access to the Agricultural market for small farmers in Southern Africa: The farmer support programme. Development Southern Africa, 4(2), $207-223$. http://dx.doi.org/10.1080/03768358708439312

\section{Copyrights}

Copyright for this article is retained by the author(s), with first publication rights granted to the journal.

This is an open-access article distributed under the terms and conditions of the Creative Commons Attribution license (http://creativecommons.org/licenses/by/3.0/). 